\title{
Prediabetes is Characterized by Higher FGF23 Levels and Higher Prevalence of Vitamin D Deficiency Compared to Normal Glucose Tolerance Subjects
}

Authors

Antoaneta Gateva'1, Yavor Assyov¹, Adelina Tsakova², Zdravko Kamenov

Affiliations

1 Department of Internal Medicine, Clinic of Endocrinology, University Hospital “Alexandrovska”, Medical University Sofia, Sofia, Bulgaria

2 Department of Clinical Laboratory and Clinical Immunology, Central Clinical Laboratory, University Hospital

"Alexandrovska”, Medical University Sofia, Sofia, Bulgaria

Key words

prediabetes, FGF23, klotho, vitamin D, insulin resistance

received 24.01.2018

accepted 29.11.2018

Bibliography

DOI https://doi.org/10.1055/a-0813-3164

Online-Publikation: 20.12.2018

Horm Metab Res 2019; 51: 106-111

(c) Georg Thieme Verlag KG Stuttgart · New York

ISSN 0018-5043

Correspondence

Antoaneta Gateva

Clinic of Endocrinology

University Hospital "Alexandrovska"

Medical University Sofia

1, GeorgiSofiiskistr.

1431 Sofia

Bulgaria

Tel.: ++359/888/720 428, Fax: ++359/888/720428

tony_gateva@yahoo.com

\section{ABSTRACT}

In the last years there is an increasing interest towards the bone as an endocrine organ and the role of bone and calcium-phosphate metabolism markers in a range of metabolic disturbances. The aim of the present study is to assess the changes of calcium phosphate metabolism markers in patients with prediabetes compared to normogycemic controls and their link to glucose disturbances and cardiovascular risk factors. In this study, 80 patients with mean age $50.4 \pm 10$.6 years were included, divided into 2 age- and BMI-matched groups - group 1 with obesity without glycemic disturbances $(n=41)$ and group 2 with obesity and prediabetes $(n=39)$. Oral glucose tolerance test (OGTT) with measurement of immunoreactive insulin was performed in all participants and levels of PTH, 25(OH)D, FGF23, and Klotho were measured. We found significantly higher levels of FGF23 in patients with prediabetes compared to normal glucose tolerance subjects $(10.4 \pm 10.7$ vs. $5.8 \pm 7.3 \mathrm{pg} /$ $\mathrm{ml} ; \mathrm{p}=0.03)$. FGF23 showed a weak positive correlation to fasting blood glucose $(r=0.224 ; p=0.048)$ but not to blood glucose on the first and second hour of oral glucose tolerance test or insulin levels. There was extremely high prevalence of vitamin $D$ deficiency in both groups. Lower levels of $25(\mathrm{OH}) \mathrm{D}$ were observed in prediabetes group, although without statistical significance $(p=0.57)$. Patients with prediabetes have higher FGF23 levels and higher prevalence of vitamin D deficiency compared to normal glucose tolerance subjects. Elevated FGF23 levels seem to be correlated more to elevated fasting blood glucose levels than to insulin resistance state of the patients.

\section{Introduction}

Prediabetes is a metabolic condition, situated between normal glucose homeostasis and diabetes and includes impaired fasting glucose (IFG) and impaired glucose tolerance (IGT). Patients with prediabetes have increased risk of developing type 2 diabetes in the future [1-3]. Insulin resistance is a typical characteristic of prediabetic patients and plays a role in the increased cardiovascular risk. Because of the fact that the risk of cardiovascular disease and macrovascular complications is increased long before diabetes diagnosis, many authors point out the components of the metabolic syndrome as main factors for increased cardiovascular risk in prediabetes. Impaired glucose regulation (diabetes, IFG, IGT) is part of the last IDF definition of metabolic syndrome in combination with abdominal obesity, hypertension, hypertriglyceridemia, and reduced HDL-cholesterol [4].

In the last years, there is an increasing interest towards the bone as an endocrine organ and the role of bone and calcium phosphate metabolism markers in a range of metabolic disturbances. Vitamin D has a critical role in calcium phosphate metabolism and bone formation, but in the last decade it became clear that vitamin D deficiency may be associated also with a range of diseases, including 
cancer, cardiovascular disease, and type 2 diabetes [5]. Vitamin D increases glucose-mediated insulin secretion, increases the expression of the insulin receptor and enhances insulin-mediated glucose transport [6, 7]. In Vitamin D deficient patients with prediabetes, treatment with vitamin $D$ improves insulin resistance and glycemic parameters [8] and reduces the risk of progression to diabetes.

Initially it was thought that vitamin D and PTH are the sole regulators of calcium phosphate metabolism. Nowadays it is known that FGF23 and Klotho also play an important role and these regulators form the so called bone-kidney-endocrine axis [9-12]. FGF23 is a phosphaturic hormone that reduces the number of sodium-phospatecotransporter2a ( $\mathrm{NaPi}-2 \mathrm{a})$ number on the proximal renal tubule membrane. It suppresses the synthesis and stimulates the degradation of 1,25-dihydroxyvitamin D3, which reduces intestinal phosphate and calcium absorption. 1,25-Dihydroxyvitamin D3 on the other hand upregulates FGF23 gene expression and closes the negative feedback loop [11]. FGF23 exerts its effects through binding to its receptors (FGF-R) in the presence of membrane protein called Klotho, acting as a co-receptor [13]. FGF23 levels are elevated in patients with chronic kidney disease $[14,15]$ and its higher levels are associated with increased mortality and cardiovascular risk [16-18].

Recent animal studies show that Klotho can act as a renoprotective factor $[19,20]$. Klotho expression is downregulated by angiotensin II and upregulated by peroxisome proliferator-activated receptor gamma (PPARY) agonists and 1,25(OH) 2 D3 [21-23]. Vitamin D deficiency and elevated FGF23 levels can decrease Klotho expression. Recent studies show reduced kidney Klotho expression in diabetic patients with normal kidney function compared to nondiabetic subjects. This suggests that reduced Klotho levels can be an early marker of diabetic nephropathy and microvascular complications in patients with diabetes [24,25].

There is no data about the levels of FGF23 and Klotho in patients with prediabetes and their link to insulin resistance and glucose homeostasis.

The aim of the present study is to assess the changes of calcium-phosphate metabolism markers in patients with prediabetes compared to normogycemic controls and their link to glucose disturbances and cardiovascular risk factors.

The study was approved by the University ethics committee for clinical projects and has been performed in accordance with the ethical standards as laid down in the 1964 Declaration of Helsinki and its later amendments or comparable ethical standards. All patients included in the study signed an informed consent for participation in the study.

\section{Patients and Methods}

Participants in the study were recruited from hospitalized patients in University hospital Endocrine clinic. In the present study, those patients were included who met the following including and excluding criteria:

\section{Inclusion criteria}

- Age 35-74 years

- IGT (glucose on 120 min of OGTT between 7.8 and $11.0 \mathrm{mmol} / \mathrm{I}$ ) and/or IFG (fasting glucose between 6.1 and $6.9 \mathrm{mmol} / \mathrm{l})$ with obesity $\left(\mathrm{BMI} \geq 30 \mathrm{~kg} / \mathrm{m}^{2}\right)$, or

- Normal glucose tolerance (NGT) and obesity (BMI $\left.\geq 30 \mathrm{~kg} / \mathrm{m}^{2}\right)$

\section{Exclusion criteria}

- Metformin or any other antidiabetic drug treatment during the last 3 months prior to study entry

- Previous cardiovascular or cerebrovascular accident (myocardial infarction, angioplasty, stenting, ischemic stroke)

- Severe renal (GFR $<60 \mathrm{ml} / \mathrm{min} / 1.73 \mathrm{~m}^{2}$ ), or liver disease (AST and/or ALT levels 3 times above the upper limit of reference range), heart failure (NYHA class III or IV)

- Malignancies

The following study methods were used:

\section{Anthropometric measurements}

- Height (cm)

- Weight $(\mathrm{kg})$

- BMI calculation (weight in kilograms divided by height in meters squared)

- Waist circumference (WC) - measurement was made midway between the 8 th rib and the iliac crest

- Hip circumference (HC) - measurement was made at the level of the greater trochanter

- Calculation of waist-to-hip ratio (WHR)

- Calculation of the waist-to-stature ratio (WSR)

- Calculation of visceral adiposity index (VAI) $=[\mathrm{WC} /(36.58+$ $(1.89 \times \mathrm{BMI})] \times(\mathrm{TG} / 0.81) \times(1,52 / \mathrm{HDL})$

- Body Composition Analysis by means of Body Impedance Analyzer (TANITA ${ }^{\text {TM }}$ TBF-215GS)

- Blood pressure measurement. Arterial hypertension was assumed if $\mathrm{BP} \geq 140 / 90 \mathrm{mmHg}$ or if the patient was taking antihypertensive medications

\section{Evaluation of carbohydrate metabolism}

- An oral glucose tolerance test (OGTT) with measurement of glucose and immunoreactive insulin (IRI) on 0,60 , and 120 min. For measuring IRI electrochemiluminiscence (ECLIA) method was used by analytics Elecsys 2010 Measuring range: $0.2-1000 \mu \mathrm{U} / \mathrm{ml}$

- HOMA index ((fasting glucose X fasting immunoreactive insulin)/22.5) was calculated

- Insulin resistance was assumed if: Fasting IRI $>17 \mathrm{mU} / \mathrm{I}$ and/or IRI $60 \mathrm{~min}>130 \mathrm{mU} / \mathrm{l}$ and/or IRI $120 \mathrm{~min}>80 \mathrm{mU} / \mathrm{l}$ and/or HOMA index $>2.6[26-27]$

\section{Laboratory tests}

- Blood count, ESR, ASAT, ALAT, GGT, total cholesterol (TC), TG, HDL, LDL, VLDL, creatinine, uric acid

\section{Metabolic syndrome (MetS)}

This was diagnosed according to the IDF and AHA/NHLBI criteria 3 out of 5 risk factors - increased waist circumference $(>80 \mathrm{~cm})$, increased TG ( $>1.7 \mathrm{mmol} / \mathrm{l})$, decreased $\mathrm{HDL}(<1.3 \mathrm{mmol} / \mathrm{l})$, increased BP (>130/85 mm $\mathrm{mg})$, and increased fasting blood glucose (>5.5 mmol/l).

\section{Measurement of bone markers}

Measurement of FGF 23 was performed by enzyme-linked immunosorbent assay (MYBIOSOURCE) - Repeatability: Coefficient of variation $<10 \%$. Measurement of Klotho was performed by enzyme-linked immunosorbent assay (MYBIOSOURCE) - Intra-assay Precision (Precision within an assay): CV\% $<8 \%$; Inter-assay Precision (Precision between assays): CV\% $<10 \% .25(\mathrm{OH}) \mathrm{D}$ was measured by electrochemiluminescence immunoassay (Roche Elecsys 
2010 Chemistry Analyzer), based on competition principle (Vitamin D total, Roche Diagnostics GmbH, 68305 Mannheim, Germany). Blood for all measurements was taken after overnight fasting, was immediately centrifuged for $15 \mathrm{~min}$ at $4000 \mathrm{rpm}$ and the serum was stored at $\left(-80^{\circ} \mathrm{C}\right)$ until the test was performed.

Subjects were categorized by their vitamin $\mathrm{D}$ status on the basis of their $25(\mathrm{OH}) \mathrm{D}$ levels as follows:

- optimal $\geq 75 \mathrm{nmol} / \mathrm{l}$ ( $\geq 30 \mathrm{ng} / \mathrm{ml}$ );

- insufficient 50-74.9 nmol/l (20.0-29.9 ng/ml); and

- deficient $<49.9 \mathrm{nmol} / \mathrm{l}(<20.0 \mathrm{ng} / \mathrm{ml}[28])$.

\section{Statistical methods}

The data were processed using the statistical package SPSS 16.0 $\left(\mathrm{IMB}^{\mathrm{TM}}\right)$. The level of significance for rejecting the null hypothesis was $p<0.05$. The following statistical methods were applied: descriptive analysis, variation analysis, Kolmogorov-Smirnov's one sample nonparametric test, Student's t-test for 2 independent samples, Mann-Whitney's nonparametric test for 2 independent samples, one-way analysis of variance between-groups ANOVA, correlation analysis. Data are presented as mean \pm SD.

\section{Results}

In the present study, we included 80 patients with mean age $50.4 \pm 10.6$ years, divided into 2 groups - group 1 (control group) with obesity without glycemic disturbances (NGT) ( $n=41 ; 6$ males, 35 females) and group 2 with prediabetes ( $n=39 ; 6$ males, 33 females). The characteristics of the 2 groups are presented in $>$ Table 1 . The 2 groups were similar in age, body weight, fat \%, BMI, WHR, WSR, and VAI. There was no significant differences between serum creatinine levels and eGFR in both groups $(75.9 \pm 12.2 \mu \mathrm{mol} / \mathrm{l}$ vs. $79.9 \pm 14.7 \mu \mathrm{mol} / \mathrm{l} ; \mathrm{p}=0.182$ and $125.2 \pm 35.6 \mathrm{ml} / \mathrm{min}$ vs. $124.5 \pm 39.8 \mathrm{ml} / \mathrm{min} ; \mathrm{p}=0.941$ respectively).

The prevalence of the classical cardiovascular risk factors determined in the study is shown on $\boldsymbol{\nabla}$ Table 2 . There was no difference in the prevalence of hypertension and dyslipidemia between the groups.

- Table 1 Anthropometric characteristics of the study groups.

\begin{tabular}{|l|c|c|}
\hline & $\begin{array}{l}\text { Group 1 } \\
\text { Obesity + NGT }\end{array}$ & $\begin{array}{l}\text { Group 2 } \\
\text { Obesity+ Prediabetes } \\
\text { (IGT and/or IFG) }\end{array}$ \\
\hline Age (years) & $50.6 \pm 9.7$ & $50.3 \pm 11.5$ \\
\hline Weight $(\mathrm{kg})$ & $97.3 \pm 17.9$ & $99.6 \pm 20.3$ \\
\hline BMI $\left(\mathrm{kg} / \mathrm{m}^{2}\right)$ & $36.6 \pm 5.2$ & $37.7 \pm 6.1$ \\
\hline$\%$ Fat tissue & $44.2 \pm 4.7$ & $44.6 \pm 6.5$ \\
\hline WHR & $0.90 \pm 0.08$ & $0.92 \pm 0.07$ \\
\hline WSR & $0.66 \pm 0.07$ & $0.68 \pm 0.08$ \\
\hline VAI & $3.2 \pm 4.0$ & $3.4 \pm 2.0$ \\
\hline All differences are not significant. & \\
\hline
\end{tabular}

Patients with prediabetes had higher levels of IRI on 0 and 120 min of OGTT and higher HOMA index although similar rates of hyperinsulinemia/insulin resistance were observed between the 2 groups ( $\triangleright$ Table 3 ). The patients with prediabetes also had higher prevalence of metabolic syndrome and a higher number of components of MetS ( $3.3 \pm 1.19$ vs. $2.8 \pm 1.07 ; p=0.04)$ compared to the patients without carbohydrate disturbances.

We found significantly higher levels of FGF23 in patients with prediabetes compared to normal glucose tolerance subjects $(10.4 \pm 10.7$ vs. $5.8 \pm 7.3 \mathrm{pg} / \mathrm{ml} ; \mathrm{p}=0.03)$ ( Table 4). Patients with insulin resistance also had higher FGF23 levels compared to controls $(9.5 \pm 10.1$ vs. $5.2 \pm 7.3 \mathrm{pg} / \mathrm{ml})$ with borderline statistical significance $(p=0.05)$. FGF23 showed a weak positive correlation to fasting blood glucose $(r=0.224 ; p=0.048)$ but not to blood glucose on the first and second hour of oral glucose tolerance test. No correlation was found to the markers of insulin resistance.

There was extremely high prevalence of vitamin D deficiency in both groups. Lower levels of $25(\mathrm{OH}) \mathrm{D}$ were observed in prediabetes group, although without statistical significance $(p=0.57)$. There was no correlation between vitamin D levels and patients' age, anthropometric indices, carbohydrate indices, and cardiovascular risk factors.

- Table 2 Cardiovascular risk factors.

\begin{tabular}{|l|l|l|}
\hline & $\begin{array}{l}\text { Group 1 } \\
\text { Obesity }\end{array}$ & $\begin{array}{l}\text { Group 2 } \\
\text { Prediabetes }\end{array}$ \\
\hline Systolic BP $(\mathrm{mmHg})$ & $138.5 \pm 16.7$ & $131.9 \pm 17.0$ \\
\hline Diastolic BP $(\mathrm{mmHg})$ & $85.4 \pm 10.0$ & $84.2 \pm 9.8$ \\
\hline Arterial hypertension $(\%)$ & 65.9 & 59.0 \\
\hline Total cholesterol $(\mathrm{mmol} / \mathrm{l})$ & $5.9 \pm 1.2$ & $5.4 \pm 1.1$ \\
\hline LDL cholesterol $(\mathrm{mmol} / \mathrm{l})$ & $3.9 \pm 1.1$ & $3.4 \pm 1.1$ \\
\hline HDL cholesterol $(\mathrm{mmol} / \mathrm{l})$ & $1.2 \pm 0.4$ & $1.1 \pm 0.3$ \\
\hline Triglycerides $(\mathrm{mmol} / \mathrm{l})$ & $1.8 \pm 1.5$ & $1.9 \pm 0.8$ \\
\hline Dyslipidemia $(\%)$ & 65.0 & 65.8 \\
\hline Smoking $(\%)$ & 46.3 & 23.7 \\
\hline All differences are not significant. & & \\
\hline
\end{tabular}

- Table 3 Markers of insulin resistance.

\begin{tabular}{|l|c|c|}
\hline & $\begin{array}{c}\text { Group 1 } \\
\text { Obesity }\end{array}$ & $\begin{array}{c}\text { Group 2 } \\
\text { Prediabetes }\end{array}$ \\
\hline IRI $0 \mathrm{~min}(\mathrm{mU} / \mathrm{l})$ & $16.7 \pm 7.4$ & $21.9 \pm 13.4^{*}$ \\
\hline IRI $60 \mathrm{~min}(\mathrm{mU} / \mathrm{l})$ & $128.2 \pm 81.8$ & $123.8 \pm 69.8$ \\
\hline IRI $120 \mathrm{~min}(\mathrm{mU} / \mathrm{l})$ & $66.0 \pm 64.0$ & $121.2 \pm 83.3^{* *}$ \\
\hline HOMA index & $3.7 \pm 1.7$ & $5.5 \pm 3.4^{* *}$ \\
\hline Prevalence of insulin resistance (\%) & 67.5 & 78.4 \\
\hline " $\mathrm{p}<0.05 ;{ }^{* *} \mathrm{p}<0.01$. & & \\
\hline
\end{tabular}


- Table 4 Calcium phosphate metabolism parameters.

\begin{tabular}{|l|c|c|}
\hline & $\begin{array}{c}\text { Group 1 } \\
\text { Obesity }\end{array}$ & $\begin{array}{c}\text { Group 2 } \\
\text { Prediabetes }\end{array}$ \\
\hline Parathormone (pmol/l) & $5.1 \pm 2.3$ & $5.1 \pm 2.0$ \\
\hline 25(OH)D (nmol/l) & $35.3 \pm 19.3$ & $28.0 \pm 13.5$ \\
\hline Vitamin D deficiency $(\%)$ & 87.5 & 94.7 \\
\hline FGF-23 $(\mathrm{pg} / \mathrm{ml})$ & $5.8 \pm 7.3$ & $10.4 \pm 10.7^{*}(\mathrm{p}=0.03)$ \\
\hline Klotho $(\mathrm{pg} / \mathrm{ml})$ & $935.8 \pm 338.5$ & $845.1 \pm 309.2$ \\
\hline$\pm \mathrm{p}<0.05$. & & \\
\hline
\end{tabular}

Klotho levels were lower in patients with prediabetes, again without statistical significance. There was no PTH levels difference between the groups.

\section{Discussion}

The role of vitamin D, FGF23, and Klotho in bone metabolism and the pathogenesis of osteoporosis is well established. Recent data, however, show that they can be linked to vascular and metabolic disturbances, especially in patients with chronic kidney disease.

Vitamin $\mathrm{D}$ deficiency has been reported as a risk factor for developing both type 1 [29] and type 2 diabetes [30-32], while vitamin D supplementation or higher levels seem to be protective [33]. A recent meta-analysis shows that for individuals in the top third vs. those in the bottom third of total baseline vitamin D levels, adjusted for age, diabetes risk factors and seasonality, have relative risk for metabolic syndrome and insulin resistance $0.86(95 \% \mathrm{Cl}$ $0.80,0.92)$, while the risk of developing diabetes was $0.81(95 \% \mathrm{Cl}$, $0.71,0.92$ ) [34]. The data on vitamin D levels in patients with prediabetes compared to controls are inconsistent. Some studies show similar 25(OH)D levels in patients with prediabetes and controls and only hypovitaminosis D combined with high parathyroid hormone concentrations was associated with glycemic dysregulation in elderly patients [35], while others find lower levels of 25(OH)D in prediabetes vs. controls [36,37]. Vitamin D deficiency however seems to be related to insulin resistance in prediabetic patients $[36,38]$, but not in normoglycemic subjects [39]. In our study, we found only a tendency towards lower levels of 25(OH)D in patients with prediabets but no relationship to insulin resistance state. Recently, we showed that obese women with PCOS have lower levels of 25(OH)D compared to lean PCOS patients [40]. There was no correlation between 25(OH)D levels and indices of glucose metabolism, but patients with optimal vitamin D levels had much lower rate of insulin resistance compared to the other 2 groups with insufficiency and deficiency. The precise mechanism of action of vitamin D on glucose homeostasis and insulin sensitivity is not clearly understood, but there are data that it is involved in beta-cell function and insulin secretion, intracellular calcium levels and postreceptor insulin signaling or autocrine/paracrine role of vitamin D in insulin target tissues [41].

FGF23 is thought to be a novel risk factor for cardiovascular morbidity and mortality not only in advanced chronic kidney disease
[42-44], but also in patients in the early stages of CKD and in the general population [45], independently from calcium, phosphate, and vitamin D levels. It is hypothesized that FGF23 could have direct negative effect on cardiovascular function. Most of the studies show elevated levels of circulating FGF23 in the individuals with type 2 diabetes [46, 47]. Serum FGF23 levels are also much higher in subjects with a first-degree family history of diabetes than in those without $[48,49]$. Not much is known about the levels of FGF23 in patients with early stages of glucose disturbances (insulin resistance and prediabetes). Our study shows significantly higher FG23 levels in patients with prediabetes compared to normal glucose tolerance subjects with similar age, BMI and cardiovascular risk factors. Its levels were higher also in patients with insulin resistance compared to those without but the levels correlated only to fasting blood glucose and not insulin resistance measures. This indicates that the main factor for FGF23 elevation is the impaired fasting glucose. A recent basic research study showed, however, that insulin signaling and the activity of sympathetic nervous system have a role in FGF23 production [50]. It is possible that early disturbances in glucose metabolism similar to overt type 2 diabetes act through the same mechanism in elevating FGF23 levels. This is supported to some extent by the elevated levels seen in relatives of type 2 diabetes patients, where mild insulin resistance with no glucose disturbances is usually observed.

To our knowledge this is the first study that evaluates FGF23 and Klotho levels in patients with prediabetes.

\section{Conclusions}

The levels of FGF23 are elevated in patients with prediabetes compared to normal glucose tolerance subjects and in insulin resistance compared to controls. FGF23 shows a weak positive correlation to fasting blood glucose but not to blood glucose on the first and second hour of oral glucose tolerance test and no correlation to the markers of insulin resistance was found. Klotho levels are lower in patients with prediabetes, but without statistical significance.

\section{Author Contributions}

Antoaneta Gateva performed the study, collected the data, and wrote the paper. Yavor Assyov performed the study and collected the data. Adelina Tsakova performed the laboratory tests. Zdravko Kamenov designed the study and reviewed the final paper.

\section{Acknowledgements}

The study was conducted with a grant from the Medical University Sofia, Medical Sciences Council - Project 5272/30.07.2014/Contract 2 - C/2014. The sponsor had no role in study design; in the collection, analysis and interpretation of data; in the writing of the report; and in the decision to submit the article for publication.

\section{Conflict of Interest}

The authors declare that they have no conflict of interest. 
References

[1] Gabir MM, Hanson RL, Dabelea D, Imperatore G, Roumain ], Bennett PH, Knowler WC. The 1997 american diabetes association and 1999 World health organization criteria for hyperglycemia in the diagnosis and prediction of diabetes. Diabetes Care 2000; 23: 1108-1112

[2] Shaw JE, Zimmet PZ, de Courten M, Dowse GK, Chitson P, Gareeboo H, Hemraj F, Fareed D, Tuomilehto J, Alberti KG. Impaired fasting glucose or impaired glucose tolerance. What best predicts future diabetes in Mauritus? Diabetes Care 1999; 22: 399-402

[3] de Vegt F, Dekker JM, Jager A, Hienkens E, Kostense PJ, Stehouwer CD, Nijpels G, Bouter LM, Heine RJ. Relation of impaired fasting and postload glucose with incident type 2 diabetes in a Dutch population; The Hoorn study. JAMA 2001; 285: 2109-2113

[4] Alberti KG, Eckel RH, Grundy SM, Zimmet PZ, Cleeman JI, Donato KA, Fruchart JC, James WP, Loria CM, Smith SC Jr. International diabetes federation task force on epidemiology and prevention; Hational heart, lung, and blood institute; American heart association; World heart federation; International atherosclerosis society; International association for the study of obesity.harmonizing the metabolic syndrome: A joint interim statement of the international diabetes federation task force on epidemiology and prevention; National heart, lung, and blood institute; American heart association; World heart federation; International Atherosclerosis society; and international association for the study of obesity. Circulation 2009; 120: 1640-1645

[5] Holick MF. Vitamin D deficiency. N Engl J Med 2007; 357: 266-281

[6] Alvarez JA, Ashraf A. Role of vitamin D in insulin secretion and insulin sensitivity for glucose homeostasis. Int J Endocrinol 2010; 351-385

[7] Teegarden D, Donkin SS. Vitamin D: Emerging new roles in insulin sensitivity. Nutr Res Rev 2009; 22: 82-92

[8] Parildar H, Cigerli O, Unal DA, Gulmez O, Demirag NG. The impact of Vitamin D Replacement on glucose metabolism. Pak J Med Sci 2013; 29: 1311-1314

[9] Kuro M, Matsumura Y, Aizawa H, Kawaguchi H, Suga T, Utsugi T, Ohyama Y, Kurabayashi M, Kaname T, Kume E, Iwasaki H, lida A, Shiraki-lida T, Nishikawa S, Nagai R, Nabeshima YI. Mutation of the mouse klotho gene leads to a syndrome resembling ageing. Nature 1997; 390: 45-51

[10] Kuro M. Endocrine FGFs and Klothos: Emerging concepts. Trends Endocrinol Metab 2008; 19: 239-245

[11] Kuro M. Overview of the FGF23-Klotho axis. Pediatr Nephrol 2010; 25 : 583-590

[12] Kurosu H, Yamamoto M, Clark JD, Pastor JV, Nandi A, Gurnani P, McGuinness OP, Chikuda H, Yamaguchi M, Kawaguchi H, Shimomura I, Takayama Y, Herz J, Kahn CR, Rosenblatt KP, Kuro M. Suppression of aging in mice by the hormone Klotho. Science 2005; 309: 1829-1833

[13] Urakawa I, Yamazaki Y, Shimada T, lijima K, Hasegawa H, Okawa K, Fujita T, Fukumoto S, Yamashita T. Klotho converts canonical FGF receptor into a specific receptor for FGF23. Nature 2006; 444: 770-774

[14] Gutiérrez OM, Mannstadt M, Isakova T, Rauh-Hain JA, Tamez H, Shah A, Smith K, Lee H, Thadhani R, Jüppner H, Wolf M. Fibroblast growth factor 23 and mortality among patients undergoing hemodialysis. N Engl J Med 2008; 359: 584-592

[15] Mitani H, Ishizaka N, Aizawa T, Ohno M, Usui S, Suzuki T, Amaki T, Mori I, Nakamura Y, Sato M, Nangaku M, Hirata Y, Nagai R. In vivo klotho gene transfer ameliorates angiotensin II-induced renal damage. Hypertension 2002; 39: 838-843

[16] Donate-Correa J, Mora-Fernández C, Martínez-Sanz R, Muros-deFuentes M, Pérez H, Meneses-Pérez B, Cazaña-Pérez V, NavarroGonzález JF. Expression of FGF23/KLOTHO system in human vascular tissue. Int J Cardiol 2013; 165: 179-183
[17] Garimella PS, Ix JH, Katz R, Chonchol MB, Kestenbaum BR, de Boer IH, Siscovick DS, Shastri S, Hiramoto JS, Shlipak MG, Sarnak MJ. Fibroblast growth factor 23, the ankle-brachial index, and incident peripheral artery disease in the Cardiovascular Health Study. Atherosclerosis 2014; 233: 91-96

[18] Jovanovich A, Ix JH, Gottdiener J, McFann K, Katz R, Kestenbaum B, de Boer IH, Sarnak M, Shlipak MG, Mukamal KJ, Siscovick D, Chonchol M. Fibroblast growth factor 23, left ventricular mass, and left ventricular hypertrophy in community-dwelling older adults. Atherosclerosis 2013; 231: 114-119

[19] Heine GH, Seiler S, Fliser D. FGF-23: The rise of a novel cardiovascular risk marker in CKD. Nephrol Dial Transplant 2012; 27: 3072-3081

[20] Kendrick J, Cheung AK, Kaufman JS, Greene T, Roberts WL, Smits G, Chonchol M. HOST Investigators. FGF-23 Associates with Death, cardiovascular events, and initiation of chronic dialysis. J Am SocNephrol 2011; 22: 1913-1922

[21] Liu J], Liu S, Morgenthaler NG, Wong MD, Tavintharan S, Sum CF, Lim SC. Association of plasma soluble a-klotho with pro-endothelin-1 in patients with type 2 diabetes. Atherosclerosis 2014; 233: 415-418

[22] Saito K, Ishizaka N, Mitani H, Ohno M, Nagai R. Iron chelation and a free radical scavenger suppress angiotensin II- induced downregulation of klotho, an anti-aging gene, in rat. FEBS Lett 2003; 551: 58-62

[23] Zhang H, Li Y, Fan Y, Wu J, Zhao B, Guan Y, Chien S, Wang N. Klotho is a target gene of PPAR-gamma. Kidney Int 2008; 74: 732-739

[24] Asai O, Nakatani K, Tanaka T, Sakan H, Imura A, Yoshimoto S, Samejima K, Yamaguchi Y, Matsui M, Akai Y, Konishi N, Iwano M, Nabeshima Y, Saito Y. Decreased renal alpha-klotho expression in early diabetic nephropathy in humans and mice and its possible role in urinary calcium excretion. Kidney Int 2012; 481: 539-547

[25] Seiler S, Wen M, Roth H], Fehrenz M, Flügge F, Herath E, Weihrauch A, Fliser $\mathrm{D}$, Heine $\mathrm{GH}$. Plasma Klotho is not related to kidney function and does not predict adverse outcome in patients with chronic kidney disease. Kidney Int 2012; 83: 121-128

[26] Arancibia C, Galgani J, Valderas JP, Morales M, Santos JL, Pollak F. Evaluation of serum insulin levels after an oral glucose load for the diagnosis of insulin resistance. Rev Med Chil 2014; 142: 1106-1112

[27] Ascaso ], Pardo S, Real JT, Lorente RI, Priego A, Carmena R. Diagnosing insulin resistance by simple quantitative methods in subjects with normal glucose metabolism. Diabetes Care 2003; 26: 3320-3325

[28] Holick MF, Binkley NC, Bischoff-Ferrari HA, Gordon CM, Hanley DA, Heaney RP, Murad MH, Weaver CM. Endocrine Society. Evaluation, treatment, and prevention of vitamin D deficiency: An Endocrine Society clinical practice guideline. J Clin Endocrinol Metab 2011; 96: 1911-1930

[29] Hyppönen E, Läärä E, Reunanen A, Järvelin MR, Virtanen SM. Intake of vitamin $D$ and risk of type 1 diabetes: A birth-cohort study. Lancet 2001; 358: 1500-1503

[30] Pittas AG, Sun Q, Manson JE, Dawson-Hughes B, Hu FB. Plasma 25-hydroxyvitamin D concentration and risk of incident type 2 diabetes in women. Diabetes Care 2010; 33: 2021-2023

[31] Scragg R, Sowers M, Bell C. Third National H, Nutrition examination survey. Serum 25 -hydroxyvitamin $D$, diabetes, and ethnicity in the third national health and nutrition examination survey. Diabetes Care 2004; $27: 2813-2818$

[32] Liu E, Meigs JB, Pittas AG, Economos CD, McKeown NM, Booth SL, Jacques PF. Predicted 25-hydroxyvitamin D score and incident type 2 diabetes in the Framingham offspring study. Am J Clin Nutr 2010; 91: $1627-1633$

[33] Mitri J, Muraru MD, Pittas AG. Vitamin D and type 2 diabetes: A systematic review. Eur J Clin Nutr 2011; 65: 1005-1015

[34] Khan H, Kunutsor S, Franco OH, Chowdhury R. Vitamin D, type 2 diabetes and other metabolic outcomes: A systematic review and meta-analysis of prospective studies. Proc Nutr Soc 2013; 72: 89-97 
[35] Karras SN, Anagnostis P, Antonopoulou V, Tsekmekidou X, Koufakis T, Goulis DG, Zebekakis P, Kotsa K. The combined effect of vitamin D and parathyroid hormone concentrations on glucose homeostasis in older patients with prediabetes: A cross-sectional study. Diab Vasc Dis Res 2018; 15: 150-153

[36] Banerjee A, Khemka VK, Roy D, Poddar ], Roy TKS, Karnam S. Role of serum adiponectin and vitamin $\mathrm{d}$ in prediabetes and diabetes mellitus. Can J Diabetes 2017; 41: 259-265

[37] Kwon HN, Lim H. Relationship between serum vitamin D status and metabolic risk factors among korean adults with prediabetes. PLoS One 2016; 11: e0165324

[38] Dutta D, Maisnam I, Shrivastava A, Sinha A, Ghosh S, Mukhopadhyay P, Mukhopadhyay $S$, Chowdhury S. Serum vitamin-D predicts insulin resistance in individuals with prediabetes. Indian J Med Res 2013; 138 : 853-860

[39] Al Masri M, Romain A], Boegner C, Maimoun L, Mariano-Goulart D, Attalin V, Leprieur E, Picandet M, Avignon A, Sultan A. Vitamin D status is not related to insulin resistance in different phenotypes of moderate obesity. Appl Physiol Nutr Metab 2017; 42: 438-442

[40] Tsakova A, Gateva A, Kamenov Z. 25(OH) vitamin D levels in premenopausal women with polycystic ovary syndrome and/or obesity. Int J Vitamin Nutr Res 2012; 82: 399-404

[41] Alvarez JA, Ashraf A. Role of vitamin d in insulin secretion and insulin sensitivity for glucose homeostasis. Int J Endocrinol 2010; 351385

[42] Gutierrez OM, Mannstadt M, Isakova T, Rauh-Hain JA, Tamez H, Shah A, Smith K, Lee $H$, Thadhani R, Juppner $H$, Wolf M. Fibroblast growth factor 23 and mortality among patients undergoing hemodialysis. N Engl J Med 2008; 359: 584-592

[43] Kendrick J, Cheung AK, Kaufman JS, Greene T, Roberts WL, Smits G, Chonchol M. FGF-23 associates with death, cardiovascular events, and initiation of chronic dialysis. J Am Soc Nephrol 2011; 22: 1913-1922
[44] Titan SM, Zatz R, Graciolli FG, dos Reis LM, Barros RT, Jorgetti V, Moyses RM. FGF-23 as a predictor of renal outcome in diabetic nephropathy. Clin J Am Soc Nephrol 2011; 6: 241-247

[45] Ix JH, Shlipak MG, Wassel CL, Whooley MA. Fibroblast growth factor-23 and early decrements in kidney function: The Heart and Soul Study. Nephrol Dial Transplant 2010; 25: 993-997

[46] Wahl P, Xie H, Scialla J, Anderson CA, Bellovich K, Brecklin C, Chen J, Feldman H, Gutierrez OM, Lash J, Leonard MB, Negrea L, Rosas SE, Anderson AH, Townsend RR, Wolf M, Isakova T. Chronic renal insufficiency cohort study group. earlier onset and greater severity of disordered mineral metabolism in diabetic patients with chronic kidney disease. Diabetes Care 2012; 35: 994-1001

[47] Vervloet MG, van Zuilen AD, Heijboer AC, ter Wee PM, Bots ML, Blankestijn PJ, Wetzels JF. MASTERPLAN group study. Fibroblast growth factor 23 is associated with proteinuria and smoking in chronic kidney disease: an analysis of the MASTERPLAN cohort. BMC. Nephrol 2012; 13: 20

[48] Schoppet M, Hofbauer LC, Brinskelle-Schmal N, Varennes A, Goudable J, Richard M, Hawa G, Chapurlat R, Szulc P. Serum level of the phosphaturic factor FGF23 is associated with abdominal aortic calcification in men: The STRAMBO study. J Clin Endocrinol Metab 2012; 97: E575-E583

[49] Hu X, Ma X, Luo Y, Xu Y, Xiong Q, Pan X, Bao Y, Jia W. Elevation in fibroblast growth factor 23 and its value for identifying subclinical atherosclerosis in first-degree relatives of patients with diabetes. Sci Rep 2016; 6: 34696

[50] Fajol A, Chen H, Umbach AT, Quarles LD, Lang F, Föller M. Enhanced FGF23 production in mice expressing PI3K-insensitive GSK3 is normalized by $\beta$-blocker treatment. FASEB J 2016; 30: 994-1001 